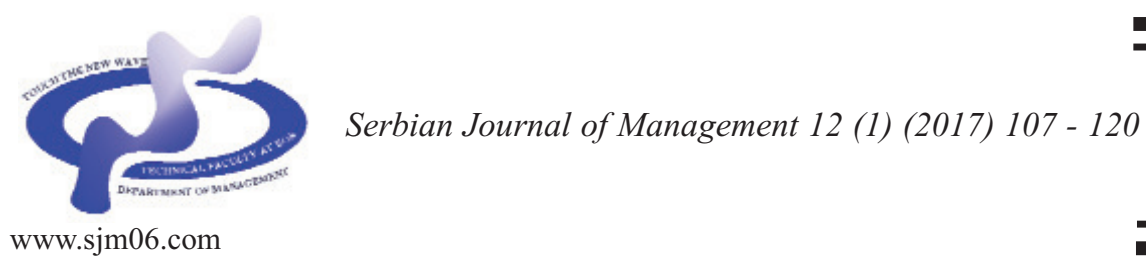

\title{
VIDEO-LECTURES: AN EFFECTIVE COMPLEMENTARY TEACHING METHOD AT BUSINESS COLLEGE
}

\author{
Jaka Vadnjal* \\ GEA College of Entrepreneurship, Dunajska 156, 1000 Ljubljana, Slovenia
}

(Received 9 May 2016; accepted 15 November 2016)

\begin{abstract}
A new teaching methodology was tested at a private college, which delivers business study programs on the undergraduate and graduate level. The combination of video-lectures with live class activities (discussions, case study solving) was used in the course which provides students competences for managing growing small and medium-sized business. Full- and part-time students participated in the two separated classes with identical study program and the same methodological approach was applied to assess the teaching approach. The main objective of the study was to examine the possible differences between the two groups of studies. In total 126 students participated in the study and the data collection was done with a survey. Several statistically significant differences were revealed. The most important finding is that part-time students were much less enthusiastic for the delivered teaching approach. It looks like they appreciated more the live interaction with other students and with the teacher and probably saw the opportunity of active participation as the main added value of the studies. The implication of the study is that course design, which includes video, should carefully take into account the two types of students addressed.
\end{abstract}

Keywords: E-learning, teaching, video, business students, full- and part-time students, entrepreneurship

\section{INTRODUCTION}

The word "video" refers to the technology of electronically capturing and broadcasting a sequence of still images representing scenes in motion. The word "learning" refers to knowledge or skills acquired through study or by being taught. The term "videobased learning" is used in the sciences of learning to define the knowledge or skills acquired by being taught via video (Maniar, 2012). From the teaching perspective, creating video-based learning content is not as simple task as creating a Word document

\footnotetext{
* Corresponding author: Jaka.vadnjal@gea-college.si
}

DOI: $10.5937 /$ sjm12-10899 
or PowerPoint slides. Video-based learning is a fairly complicated medium as compared to other media such as text, images, or audio. It requires expertise from different domains (Maniar, 2012). Various multimedia learning materials can support the learners as a method to get advanced learning effect directing emotions to affect learning performance. It is important to understand what is the most important or influencing factor to learner in online education. However, assessing the effects of multimedia materials in e-learning emotions has rarely been investigated (Jeong \& Yeo, 2014).

How affective video-based learning really is, can be distinguished by type of teaching style applied to create and deliver the content versus the learners' content processing capabilities. For affective video-based learning, one of the critical considerations is cognitive pace at which the amount of information can be processed per time unit. The amount depends on the familiarity and meaningfulness of the information (Miller, 1956; Simon, 1974). Video-based learning delivered in shorter length pieces may provide more learning as opposed to larger pieces of video material (Maniar et al., 2007). The availability of a variety of media technologies allow users to record audio and video files in a reasonably short amount of time leading to the increased use of video cameras in lectures and other learning environments (Odhabi \& Nicks-McCaleb, 2011). Video-recorded presentations integrated into learning environment are recognized as highly effective at enhancing the learning outcomes and enriching the classroom education (Tugba, 2012).

In today's economy characterized by industrial change, globalization, increased intensive competition, knowledge sharing and transfer, and information technology revolution, traditional classroom education or training does not always satisfy all the needs of the new world of lifelong learning. Learning is shifting from instructor-centered to learner-centered, and it can be undertaken anywhere. E-learning is a flexible and personalized way to learn. It offers learningon-demand opportunities and reduces learning cost. Armed with the advanced information and communication technologies, e-learning is having a farreaching impact on learning in the last decade or two (Zhang \& Nunamaker, 2003).

The main motivation to run this study and to write the paper was to examine the attitudes of the business students against this, for many of them very new and unknown method of teaching and learning. Encouraged from some previous investigation when quite large differences in study attitudes and processing capabilities of full and part-time students were revealed (Whitlach, 1983), the research was conducted with the ambition to see whether there are also differences in the case of opinions regarding the video-based lectures. The additional motivation and justification of the need for this kind of research for the special needs and requests of part-time students is the increasing number of their participation in the higher education in the last couple of decades (Kasworm, 2003).

The structure of the paper goes as follows. In the theoretical background section, some aspects of e-learning and teaching and their applications for higher education, also in the broader field business and within it of entrepreneurship, are examined. Next, the methodology is explained and results displayed, interpreted and commented. Last, the hypotheses are verified for their confirmation and some implications for future research in the field and for future 
design of e-learning and teaching methods with the combination of some more traditional educational methods are suggested.

\section{THEORETICAL BACKGROUND AND HYPOTHESES DEVELOPMENT}

A critical attribute of video is the ability to use both auditory and visual symbol systems. The combined use of visual and auditory symbol systems results in more recall for teaching and learning activities than presentations, which are supported only by visual means or only by audio. The visual symbol system serves as the primary source of information, and the audio symbol system is used to elaborate it (Kozma, 1991). Interactive video-based learning provides individual control over random access to content, which may lead to better learning compared to non-interactive video-based learning (Daniel \& Marquis, 1979). With the advances in technology, streaming media along with web technologies (multimedia) has become very important delivery medium for accessing video-based learning on demand, including anytime and anywhere learning using mobile devices. The use of video as a technological tool has a positive impact on students' viewing and critically evaluating their tasks. There are several potential advantages of integrating technology into face-to-face instructions, and video learning is worthy of further investigation (Kırkgöz, 2011).

Motivation could be one of the most essential factors that learners may be dependent upon for successful learning. The motivation model of (1) attention, (2) relevance, (3) confidence, and (4) satisfaction was developed in response to a desire to find more effective ways of understanding the major influences on the motivation to learn and for systematic ways of identifying and solving problems with learning motivation. A study carried out by Keller (2001) suggested that this model may be useful and effective in support of designing for these dynamic aspects of motivation. The model defines four major conditions that have to be met for people to become and remain motivated. Video-based learning that provides attention, relevance, confidence, and satisfaction should therefore be able to promote learners' motivation. Video is a very effective tool to be used for e-learning. Most of the available video conferencing systems suffer a main drawback represented by the lack of eye contact, which means interaction, among participants (Halawani et al., 2011). However, it turns that the ways the video footage was shot are very important. The quality of the picture is important but not crucial. In making video the message of communication between the teacher and the audience can be tracked with zooming to both, the speaker and the audience, which can be only done by careful design of the integral video piece (Erickson, 2011).

E-learning indicates the provision of education and training on the internet. The internet offers several advantages compared with other mass media. It (1) enables access to a large amount of information previously known only to individuals; (2) it is flexible, permitting the use of images or video; and (3) it allows linking to sites on a specific subject, thus contributing to further expand knowledge. The application of e-learning and teaching requires the development of models that involve: (1) selection and creation of e-learning platforms, (2) creation and technological adaptation of multimedia 
teaching modules, (3) creation and management of a unified catalogue of teaching modules, (4) planning training actions, (5) definition of training pathways, (6) identification of levels of teaching and technological complexity of support tools, (7) sharing an organisational and methodological model, (8) training the trainers, (9) operators' participation and relational devices, (10) provision of training, (11) monitoring progress of the activities, and (12) measurement of the effectiveness of training (Pinto et al., 2008). Although information and communication technology seems to be a promising tool in an educational context, many teachers are reluctant to integrate it in their daily practice. Persuasive communication focusing on positive outcomes and skills based training seems to be appropriate intervention to promote a positive attitude towards digital learning material (Van Acker et al., 2013). The importance of e-learning and teaching has significantly increased recently. One common feature of applications is usercentricity. Understanding user behavior is critical especially in user-centered applications. Current user pattern mining techniques should take into account behavioral and educational theories for distance learning in order to be efficient (Vassiliandis \& Stefani, 2012).

E-learning is becoming increasingly popular as a tool for developing human resource training plans in large corporations. An e-training platform has been designed and implemented to explore the possibilities of e-training in large corporations (Granda et al., 2013). E-learning is increasingly being adopted as an instructional media, and has moved from a niche solution launched in the defense and aerospace industries, to become adopted across the majority of industries and within education worldwide. E-learning is not however suited for all types of learning outcome and for all instructional situations. Different media is differently suitable for of e-learning for a particular learning outcome. There are seven key dimensions: (1) learning task, (2) media attributes, (3) grouping strategy, (4) learning context, (5) learner characteristics, (6) instructional management and (7) cost effectiveness. There are several decision factors for selecting e-learning and the development of detailed guidance within each decision area to enable an assessment of suitability of e-learning and teaching to be made (Huddlestone \& Pike, 2008).

Mobile learning as a sub-group of elearning which is understood as the information and communication technologies devices used by students as part of their everyday life such as hand phones in combination with social media platforms and other pedagogical methods such as mini lectures, field visits, and walking tours can greatly enrich learners' experience and produce learning outcomes on the basis of elearning and teaching provided their usage is easy and effectively integrated into the instructional strategy (Menkoff \& Bengtson, 2012).

The two important components of a model for e-learning and teaching are "teaching presence" and "community". The community plays a critical role in academic success and persistence in higher education. The teaching presence, viewed as the core roles of the online instructor, can be a good mechanism for developing learning community in online environments. There is a significant link between students' sense of learning community and effective instructional design and "directed facilitation" from the side of course instructors. Despite some assertions that 
younger students are too sophisticated to "feel at home" in largely text-based learning environments, no significant effects were found by age differences examined (Shea et al., 2006).

There role of the e-learning and teaching systems in the higher education is becoming more and more active. The number of teachers that are currently using e-learning and teaching in their professional activities has been increasing in the last years (Moise et al., 2012). The recent advances in information technologies with the increasing interest of large number of individuals to get higher education have led to the rapid evolution of online distance education. Distance e-learning and teaching has a possibility to offer education to students who are too busy or being physically unable to attend face-to-face classroom lectures (Al Saiyd \& Al Sayed, 2011).

Creative destruction, the creation of new industries and the destruction of old industries, is a very abstract concept. People teaching entrepreneurship, where creative destruction is a central feature according to Schumpeter (1942), often struggle to communicate the dynamism of industry evolution where industry disruption can yield innovation, entrepreneurial opportunities and new wealth. Information visualization is a resource for entrepreneurship education (Noyes \& Deligiannidis, 2012). To develop entrepreneurship education and to cultivate entrepreneurial talents can help alleviate the current severe employment situation for college students and improve the overall quality of them to realize the transition from entrepreneurship awareness to entrepreneurial actions (Zufeng \& Chunling, 2011).

The decision to undertake paid employment while studying emerges as one of the key determinants of student satisfaction. Students, who hold a part-time job while studying, are more likely to express less satisfaction with their college experience (Moro-Egido \& Panades, 2010). The strategy of asking student to watch the same videos on the course was recognized by them as a crucial element in facilitating their reflection on their changing conceptions of good teaching (Yung et al., 2007). The following hypotheses were derived from the literature review and combined by some intuitive thinking of the researcher:

H1: The video-based e-learning and teaching is recognized as an effective complementary learning and teaching method to train students in entrepreneurial skills (Zufeng \& Chunling, 2011).

H2: The combined learning and teaching methodology increases the motivation of business students (Halawani et al., 2011).

H3: The influence of youth as being members of digital generation is not significant (Shea et al., 2006).

H4: Part time students are generally more demanding regarding the several aspects of video-based e-learning and teaching (MoroEgido \& Panades, 2010).

\section{METHODOLOGY AND SAMPLING}

Two groups of undergraduate business students pursuing studies in entrepreneurship were committed to be tested with first time delivery of a course using, for them new, innovative method of teaching and learning which was partly based on video-lectures 
recorded with the course supervisor in the main acting role. The video recordings and the final production of the clips with course content were directed and shot by professionally trained person with experience in documentary movies and professional equipment (two cameras for recording from different angles) was utilized. All the materials were carefully prepared well before the course started. The course titled »Managing growing business « is one of the last courses scheduled in the last semester of the three years' business oriented undergraduate study program. The program is run by a small institutionally young private business college in Slovenia, established in 1996. The course supervisor is an experienced teacher who also used to be one of the most successful post-transition entrepreneurs in the country and also publicly well known, often invited to speak for different media and public occasions. As such, being more a practitioner rather than scholar, he has been for many years enjoying a very high level of appreciation and popularity among the college students.

The basic idea of the classroom teaching experiment was that students were asked to watch the video with the taped lecture. In the beginning of the planned teaching activity, it was meant that students would watch the video lectures at home before the live classroom lecture. However, this intention by the course instructor failed. The reason for this may be that students seldom meet the expectations of teacher and do the requested pre-class preparation. So, it was decided to divide students in groups of four people and made them watch the video lectures during the live class time. After that, there was no more ex-cathedra lecturing in the classroom but only different assignments (numerical calculations, case studies analyses, discussions etc.) which logically followed and extended the content of the videolecture. The assignments were done in teams of students and consecutively moderated and supervised by the teacher. Certain criteria were given in advance to enforce a small scale competition among groups in solving some of the case study issues presented in video lectures and, at the end of the class session, a winning team was recognized and given an appraisal from the students.

At the end of the course, all students were surveyed in order to realize whether there were any differences in opinions of full-time and part-time students. The full- and the parttime students study in separate groups but follow the same curriculum with the same teacher. In our case, both groups were given the same assignments in the six consecutive weeks of the course duration. Thus, the two samples can be regarded entirely comparable. There were 66 part-time students in average 32 years old, half of them working full time and half of them working in average half shift work. The full-timers (64 of them were in average younger (23 years) and only $25 \%$ were working between 20 and 40 hours a week. Regarding the gender, the both groups were balanced. It is obvious that part-time students are much more experienced as the result of age and more extensive working references and, as such may have different processing capacity and cognitive pace.

The data was collected by surveying the students at the last scheduled lecturing session of the running course, separately for the full- and the part-timers. Surveying students about their opinions is the standardized part of the quality insurance system implemented at the college, which hosts and delivers the study program. According to the written protocol of rules 
and procedures, the responding is done individually on paper-printed forms. The surveying action is done anonymously and without the presence of the teacher in the classroom, thus disabling possible influence is excluded. When novelties are introduced into the courses and programs, even more focus is given to observe the reactions and feedback of the students. Since the college has several part-time students due to the college's traditional applicable and practical study orientation, they run separate programs for them, which are regarding the content highly comparable to the full-time delivery of the program, but the organization is adapted to the needs of students who usually take regular jobs and study at once. Generally, there are less contact hours available. These are provided mostly in the late afternoon or even weekend time slots.

For the survey, the students were asked to express their level of agreement with total of 29 statements based on Likert-scale in which grade 1 (one) meant full disagreement with the statement and 5 (five) stood for the full agreement with the statement. The whole experiment together with the data collection took part in the late spring 2013. The calculations of the main demographics and means and the t-test to test differences between the means were done with MS Excel from MS Office 2010.

\section{RESULTS}

The results collected and calculated from the survey are displayed in the Table 1 . The mean values are given separately for the fulland the part-time students and $p$ value of the t-test and possible statistically significant differences are displayed with asterisk $(*)$ symbol. Several meaningful differences are revealed in order to assist for the confirmation or rejection of the suggested hypotheses. Although without any proven statistical significance, it can be said that part-time students were watching video a little bit less intensively, but followed more the teacher's instructions to watch the videos in advance, before the scheduled life classes. However, part-times students watched the recorded lecture significantly less frequently, both before the lecture in the team of colleagues and within the next 24 hours after the classes. This may be interpreted with their time constraints and different processing capacity which can be derived from the fact that video is a non-interactive method.

There were virtually no meaningful differences between the opinions of students regarding usefulness of the video for the studies (assistance to do home-works, repetition of the content) and also opinions about more technical characteristics (the length of the video, quality of sound and picture etc.). This probably also leads to the shared disagreement of the both groups of students, that watching video is a very passive activity with the great lack of interaction. Generally, learning is supposed to be a very proactive activity thus, on the contrary, watching video turns to be a quite inactive and, with lesser self-involvement of participants, activity when in the context of learning.

There were no significant differences in opinions regarding the intention to watch videos again in the near future when studying for the final exam, regarding the selection of topics and when asked the negative statement whether the video lectures were maybe seen as "completely useless" for a certain students. From the mean values which are merely around the 
value 4 (four) for positive, and less than 2 (two) for the negativistic statement, it can be generalized that there is a high level of support and favorable feelings against the presented method of teaching.

When suggested, that video content could entirely replace the classical lectures at the college premises, full-time students were somehow indifferent and would not clearly decide for one side or another, while parttime students expressed significantly lower level of agreement so, it can be stated, that they actually confirmed their aversion against this issue. Part-time students were ambivalent regarding the statement that the combination of classical teaching and video lectures was an effective learning combination. At the same time, full-time students were far more enthusiastic about it and the difference in opinions is significant. Full time students would expand the tested teaching and learning methodology to other courses within the program with significantly higher level of agreement. Generally, both groups of students highly disagreed, that video lectures would be useless because they were too lazy to watch them in advance before the life classes. There is a very balanced high level of agreement that students would watch the video lectures again before the exam and that the selection of topics was very appropriate.

Members of neither of the two groups were very enthusiastic about the idea that a video-based university could be organized, however the part-time students were even significantly more reluctant to this idea. Fulltime students were somehow indifferent regarding the estimation that they would change nothing in the existing course structure while, on the other hand, part-time students showed significantly higher level of disagreement with the proposed future changes. Consequently, part-time students agreed significantly less with the idea that other teachers too, should organize their sessions in a similar way and they would be more inclined to classical way of teaching. Although the both groups evaluated the lectures to be very interesting an inspiring, the part-time students showed a significantly lower level of enthusiasm regarding this. Again, there were part-time students who significantly agreed less, that the intensity of the work-load was just the appropriate one for gaining planned competences in the course curricula.

Also when team-work was considered and examined part-time students expressed significantly less agreement with the statements that (1) working in groups was useful; that (2) competition among groups brought more motivation into the learning process; that (3) watching the video in teams before the lectures was effective; and that (4) the amount of absorption of the learned content was higher. Thus, it can be generally summarized, that part-time students showed much lower level of approval for the teamwork within the context of the video-based lecturing sessions.

The first hypothesis, suggesting that the video-based e-learning and teaching can be recognized as an effective and complementary learning and teaching method to train students in entrepreneurial skills, can be regarded as confirmed, since majority of mean values for responses to statements which cover the usefulness and applicability of the tested teaching and learning method are far beyond the mean value 3 (three). These findings support previous theoretical confirmation of Zufeng \& Chunling (2011) who claimed that combination of e-courses with entrepreneurial education may effectively 
Table 1. Opinions of full time and part-time students on video lectures

\begin{tabular}{|c|c|c|c|c|}
\hline Statement & $\begin{array}{l}\text { Full-time } \\
\mathrm{N}=64\end{array}$ & $\begin{array}{l}\text { Part-time } \\
\mathrm{N}=66\end{array}$ & $\begin{array}{l}P \\
(t-t e s t)\end{array}$ & Sig. \\
\hline I was regularly watching the video contents. & 4.0 & 3.6 & 0.1 & \\
\hline Usually, I watched the video before the lectures. & 2.6 & 3.1 & 0.1 & \\
\hline I usually watched the video within 24 hours after the lecture. & 2.8 & 1.9 & 0.0 & $* * *$ \\
\hline I watched video in my study team before the lectures. & 4.5 & 3.8 & 0.0 & $* *$ \\
\hline Video was of a great assistance to prepare home-works. & 3.9 & 3.7 & 0.1 & \\
\hline $\begin{array}{l}\text { Video was most useful to repeat the content and refresh my } \\
\text { memory what happened at the lectures. }\end{array}$ & 4.0 & 3.6 & 0.1 & \\
\hline The time length of the videos was appropriate. & 3.7 & 3.8 & 0.4 & \\
\hline $\begin{array}{l}\text { The quality of the record (picture, sound) was good enough } \\
\text { for the pedagogical purposes. }\end{array}$ & 4.0 & 3.8 & 0.2 & \\
\hline $\begin{array}{l}\text { Watching video is a very passive activity, similar to watching } \\
\text { TV. }\end{array}$ & 2.8 & 2.5 & 0.1 & \\
\hline Video content could entirely replace the lectures. & 3.1 & 2.5 & 0.0 & $*$ \\
\hline Combination of life lectures and videos is a very good option. & 4.1 & 3.1 & 0.0 & $* * *$ \\
\hline It would be good to use video content in other courses. & 3.8 & 3.1 & 0.0 & $*$ \\
\hline $\begin{array}{l}\text { Lectures were useless for me because I was too lazy to watch } \\
\text { video in advance. }\end{array}$ & 1.5 & 1.7 & 0.2 & \\
\hline $\begin{array}{l}\text { I will again watch the videos when I will study for the final } \\
\text { exam. }\end{array}$ & 4.2 & 4.2 & 0.5 & \\
\hline $\begin{array}{l}\text { The selection of topics to be presented on video was the right } \\
\text { one. }\end{array}$ & 4.0 & 3.9 & 0.4 & \\
\hline A video university could be organized with no life lectures. & 2.7 & 1.8 & 0.0 & $* * *$ \\
\hline I would change nothing in the course. & 3.1 & 2.5 & 0.0 & $*$ \\
\hline I would prefer lectures in a classical way. & 2.4 & 3.2 & 0.0 & $* *$ \\
\hline $\begin{array}{l}\text { Other lecturers should organize their lectures in a similar } \\
\text { way. }\end{array}$ & 3.7 & 2.6 & 0.0 & $* * *$ \\
\hline Lectures were very interesting. & 4.1 & 3.6 & 0.0 & $* *$ \\
\hline The intensity of work in the classroom was appropriate. & 4.0 & 3.2 & 0.0 & $* * *$ \\
\hline I find the work in groups very useful. & 4.1 & 3.1 & 0.0 & $* * *$ \\
\hline $\begin{array}{l}\text { Competition among groups motivated me to prepare more } \\
\text { for the lectures. }\end{array}$ & 3.9 & 2.8 & 0.0 & $* * *$ \\
\hline Our team should have won but it did not which was not fair. & 2.8 & 2.0 & 0.0 & $* *$ \\
\hline $\begin{array}{l}\text { I support the idea to watch video in the team during the } \\
\text { lectures. }\end{array}$ & 4.0 & 2.4 & 0.0 & $* * *$ \\
\hline I liked team work because I believed I learned. & 4.1 & 3.0 & 0.0 & $* * *$ \\
\hline
\end{tabular}

Source: Own research, 2013

Note: $\left({ }^{* *}\right)$ means significance at 0.001 level, $\left({ }^{* *}\right)$ at 0.05 level and $\left({ }^{*}\right)$ at 0.1 level 
guide the transition of entrepreneurial actions from entrepreneurial awareness is of great importance.

The combined learning and teaching methodology increases the motivation of business students, which is the statement of the second hypothesis. This can be regarded as valid and confirmed. This finding can be rationalized with the claim that video conferencing is a very effective tool to use for e-learning. Most of the available video conferencing systems suffer a main drawback represented by the lack of eye contact between participants (Halawani et al., 2011) which was over-ruled in our study.

The majority of responders evaluate highly the interference between classical teaching and learning approaches and the video-based methodology. The influence of youth, as a fact of being members of the digital generation, is not significant, so the third hypotheses cannot be entirely confirmed although the part-time students were in average more than five years older than the full-time students. However, the deeper analysis resulted in no statistically significant findings, which turns to be somehow similar to the previous findings of Shea et al. (2006) which also found no statistical significant difference between younger and older students when their inclination to e-learning was discussed.

The last, fourth hypothesis, saying that part time students are generally more demanding regarding the several aspects of video-based e-learning and teaching, can be entirely confirmed because majority of statements were characterized with statistically significant differences in opinions between the two groups. Another study revealed that part-time students cannot take full advantage of the facilities and amenities available to full-time students.
Lack of access or participation may lead part-time students to assess their academic performance more negatively (Moro-Egido \& Panades, 2010). To summarize, three hypotheses may be fully confirmed and one hypothesis is only partly confirmed.

\section{DISCUSSION AND IMPLICATIONS}

As highlighted in the methodology section, the data was collected in the context of the quality integral control system, which is installed at the college. The main objective of the paper was to investigate the possible differences in the attitudes and opinions of full- and part-time students of the undergraduate business studies. The main finding from the study is that part-time students were much less enthusiastic with the offered video-based methodology of teaching and learning. There may be several reasons for this. The part time students were older and had more working experience. Taking this into account, they probably have different expectation and views, what would be the added value of the life and face-toface (not video) lecturing sessions. They probably value higher the possibility of interaction with the other class participants and with the teacher. Also, they appreciate discussion and opinions of other students. They regard the teacher as an authority and they would appreciate an opportunity for direct interaction with him.

Generally, video-based teaching and learning is embedded into the more classical higher education teaching and learning system. Thus, a more complex system of blended learning is seen as a complementary study method, which would probably never be in the position to entirely replace the classical study approaches. This is an 
important contribution for possible strategic rethinking of future development of the college but the experience can influence also other study course developers also at other institutions. There are more and more higher education providers worldwide which are even operated completely on-line. The effectiveness of the final outcome of these studies has not been complexly investigated so far. However, the market segment which is currently targeted by the college is sending a clear message that they expected a more technically advanced support of studies but would not replace entirely the classical methods.

Regarding the quality control at the college, where the experiment and the research took place, it can be suggested, that probably more time should be devoted into studying the difference in needs and expectations from the part-time students. From the findings, it is clear, that completely identical methods probably cannot be used for the two groups of students. Consequently, methodology of teaching to part-time students should be examined carefully and feed-back of students together with assessing achievement of learning objectives should be measured on annual basis. Retrieving from findings of assessment, modifications and adaptations of curricula should be done.

There are several identified needs for the future research. One is for sure expanding the research on the differences in opinions of the full- and part-time students also in other courses. Video-based teaching and learning is also tested in some other courses which gives another opportunity for examination of possible differences and consequently program adaptations and modifications. A limitation of this study is that it was conducted on a limited sample and only for the one course. Suggested further research would therefore also add to additional validation of this particular study.

\section{CONCLUSIONS}

Regarding the main results' summary, it can be said that part-time students were watching video slightly less intensively, but followed more the teacher's instructions to watch the videos in advance, before the scheduled life classes. However, part-times students watched the recorded lecture significantly less frequently, both before the lecture in the team of colleagues and within the next 24 hours after the classes. There is a common opinion that watching video is a very passive activity with the great lack of interaction. When suggested, that video content could entirely replace the classical lectures at the college premises, the students were somehow indifferent and would not clearly decide. The students would expand the tested teaching and learning methodology to other courses within the program. Generally, students highly disagreed, that video lectures would be useless. Participants were not very enthusiastic about the idea that a video-based university could be organized, however the part-time students were even significantly more reluctant to this idea. Part-time students showed much lower level of approval for the team-work within the context of the video-based lecturing sessions.

The first hypothesis, suggesting that the video-based e-learning and teaching can be recognized as an effective and complementary learning and teaching method to train students in entrepreneurial skills, can be regarded as confirmed. The combined learning and teaching 
methodology increases the motivation of business students, which is the statement of the second confirmed hypothesis. The influence of youth, as a fact of being members of the digital generation, is not significant, so the third hypotheses cannot be entirely confirmed although the part-time students were in average more than five years older than the full-time students. The last, fourth hypothesis, saying that part time students are generally more demanding regarding the several aspects of video-based e-learning and teaching, can be entirely confirmed.

In the era of eve developing ICT technologies there is more and more search for the new, more innovative and, most importantly, more effective ways of teaching and learning. Among them, video-based learning, whether in the form of taped material, direct broadcasting or webinars, may possess more and more important role in the future, which is not that clear. Namely, new interactive media are developing fast (internet $\mathrm{TV}$, interactive $\mathrm{TV}$, internet of things) leaving enough room for innovative thinkers in the field of education. However, those who would dare to experiment in this very traditionalistic field should provide a lot of consideration about appropriateness of different methods and technologies. Thus, this study may contribute a small piece of methodological understanding of the e-based teaching and learning.

Further research is planned to be expanded into another courses that would be based on video-based learning. This should be with the same group of students in order to asses, whether the findings of the research can be generalized or, what can be

\title{
ВИДЕО - ПРЕДАВАЊА: ЕФЕКТИВНИ МЕТОД ДОДАТНОГ УЧЕЊА НА ПОСЛОВНИМ ШКОЛАМА
}

\author{
Jaka Vadnjal
}

\section{Извод}

На приватном колеџу који реализује студијске програме из области пословања, на додипломском и мастер нивоу, тестирана је нова методологија предавања. На курсу који студентима даје компетенције за управљање растом малих и средњих предузећа, коришћена је комбинација видео-предавања и реалних активности на часу (дискусије, решавање студија случаја). У две раздвојене групе су укључени редовни и ванредни студенти, уз идентичан студијски програм и уз примену идентичног методолошког приступа, како би се проценио наставни метод. Основни циљ проучавања је био у процени могућих разлика у наведене две групе студената. У студији је укупно учествовало 126 студената и подаци су сакупљени применом упитника. Откривено је неколико статистички значајних разлика. Најзначајније откриће је да су ванредни студенти значајно мање заинтересовани за овакав приступ настави. Делује да они више цене реалну интеракцију са другим студентима и са наставником, те да као главну додатну вредност студија виде управо активно учествовање. Импликација ове студије је да дизајн наставног курса, који укључује видео, треба пажљиво да узме у обзир разлике између две врсте студената који су анализирани.

Кључне речи: Е-учење, видео предавање, студенти пословања, редовни и ванредни студенти, предузетништво 
speculated, may be also conditioned by the discipline taught in the described way. Nevertheless, results should be taken into consideration for further planning of the video-based methods to be implemented in the higher education curricula.

\section{References}

Al Saiyd, N.A., \& Al Sayed, I.A. (2011). Multimedia distance e-learning system for higher education students. In Snasel V., Platos J. \& El-Qawasmeh E. (Eds.) Communications in Computer and Information Science, 188, 356-367.

Daniel, J., \& Marquis, C. (1979). Interaction and independence: Getting the mixture right. Teaching at a Distance, 15 (1), 25-44.

Erickson, E. (2011). Reflections on Practice, Teaching/Learning, Video, and Theorizing in Koschmann, F. (ed.) Theories of Learning and Studies of Instructional Practice. Springer Science+Business Media, 385-402.

Granda, J.C., Nuño, P., Suárez, F.J., \& Pérez, M.A. (2013). E-pSyLon: a synchronous e-learning platform for staff training in large corporations. Multimedia Tools and Applications, 66 (3), 431-463.

Halawani, A., Li, H., \& Anani, A. (2011). Building eye contact in e-learning through head-eye coordination. International Journal of Social Robotics, 3 (2), 95-106.

Huddlestone, J., \& Pike, J. (2008). Seven key decision factors for selecting e-learning. Cognition, Technology \& Work, 10 (3), 237247.

Jeong, H., \& Yeo, S. (2014). The quality model for e-learning system with multimedia contents: a pairwise comparison approach. Multimedia Tools and Applications, 73 (2), 887-900.
Kasworm, C.E. (2003). Setting the stage: Adults in higher education. Meeting the special needs of adult students. New Directions in Students Services, 102. Willey Periodicals, 2-10.

Keller, J.M. (2001). Effectiveness of motivationally adaptive computer-assisted instruction on the dynamic aspects of motivation. Educational Technology Research and Development, 49 (1), 5-22.

Kırkgöz, Y. (2011). A blended learning study on implementing video recorded speaking tasks in task-based classroom instruction. Turkish Online Journal of Educational Technology, 10 (4), 1-13.

Kozma, R.B. (1991). Learning with media. Review of Educational Research, 61 (2), 179-211.

Maniar, N., Bennett, E., Hand, S., \& Allan, G. (2007). The effect of mobile phone screen size on video based learning. Journal of Software, 3 (4), 51-61.

Maniar, N.J. (2012). Video-based learning. In N. Seel (ed.), Encyclopedia of the Sciences of Learning, Springer Science+Business Media, 3403-3404.

Miller, G.A. (1956). The magical number seven plus or minus two: Some limits of our capacity for processing information. Psychological Review, 63 (1), 81-97.

Menkoff, T., \& Bengtson, M. L. (2012). Engaging students in higher education through mobile learning: lessons learnt in a Chinese entrepreneurship course. Educational Research for Policy and Practise, 11 (3), 225-242.

Moise, G., Suditu, M., \& Netedu, L. (2012). The implementation of the e-learning systems in higher education - sharing the work experience from Petroleum-Gas University of Ploiești. E. Popescu et al. (Eds.): Advances in Web-Based Learning ICWL 2012 11th International Conference, 
Sinaia, Romania, September 2-4, Springer Berlin/ Heidelberg, 343-348.

Moro-Egido, A.I., \& Panades, J. (2010). An analysis of student satisfaction: full-time vs. part-time students. Social Indicators Research, 96 (2), 363-378.

Noyes, E., \& Deligiannidis, L. (2012). 2D and $3 \mathrm{D}$ visualizations of creative destruction for entrepreneurship education. Z.S. Hippe et al. (Eds.): Human - Computer Systems Interaction, AISC 99, Part II, 277-294.

Odhabi, H., \& Nicks-McCaleb, L. (2011). Video recording lectures: Student and professor perspectives. British Journal of Educational Technology, 42 (2), 327-336.

Pinto, A., Selvaggi, S., Sicignano, G., Vollono, E., Iervolino, L., Amato, F., Molinari, A., \& Grassi, R. (2008). E-learning tools for education: regulatory aspects, current applications in radiology and future prospects. La Radiologia Medica, 113 (1), 144-157.

Schumpeter, J.A. (1942). Capitalism, Socialism and Democracy. New York: Harper and Row.

Shea, P., Li, C.S., \& Pickett, A. (2006). A study of teaching presence and student sense of learning community in fully online and web-enhanced college courses. Internet and Higher Education, 9 (3), 175-190.

Simon, H.A. (1974). How big is a chunk? Science, 183 (4124), 482-488.

Tugba, O.T. (2012). Student Perceptions of an Educational Technology Tool: Video Recordings of Project Presentations. Procedia - Social and Behavioral Sciences, 64 (9), 133-140.

Vassiliandis, B., \& Stefani, A. (2012). Adaptation strategies: A comparison between e-learning and e-commerce techniques. L. Iliadis et al. (Eds.): AIAI 2012 Workshops, IFIP AICT 382, 115-124.

Van Acker, F., Van Buuren, H., Krejins,
K., \& Vermeulen, M. (2013). Why teachers use digital learning materials: The role of self-efficacy, subjective norm and attitude. Education and Information Technologies, 18 (3), 495-514.

Whitlach, J.B. (1983). Library use patterns among full- and part-time faculty and students. College \& Research Librarie, 44 (2), 141-152.

Yung, H.W.Y., Wong, S.L., Cheng, M.W., Hui, C.S., \& Hodson, D. (2007). Tracking pre-service teachers' changing conceptions of good science teaching: The role of progressive reflection with the same video. Research in Science Education, 37 (3), 239259.

Zhang, D., \& Nunamaker, J.F. (2003). Powering e-learning in the new millennium: An overview of e-learning and enabling technology. Information Systems Frontiers, 5 (2), 207-218.

Zufeng, L., \& Chunling, Z. (2011). Research on entrepreneurship education based on e-commerce. M. Zhu (Ed.): Computing and Intelligent Systems, International Conference, ICCIC 2011, Wuhan, China, September 17-18, 2011. Proceedings, Part IV, Communications in Computer and Information Science, 234, 381-388. 